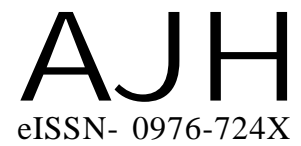

Received : 29.10.2017

Revised : 15.11 .2017

Accepted : 22.11.2017

Members of the Research Forum

Associated Authors:

${ }^{1}$ Horticultural Research Station, (SKLTSHU), Dasnapur, ADILABAD

(TELANGANA) INDIA
Author for correspondence : V. VIJAYA BHASKAR College of Horticulture, Dr. Y.S.R. Horticultural University, Anantharajupeta, KADAPA (A P.) INDIA
THEASIAN JOURNAL OF HORTICULTURE

Volume 12 | Issue 2 | December, 2017 | 244-246

Visit us -www.researchjournal.co.in

RESEARCH PAPER

DOI : 10.15740/HAS/TAJH/12.2/244-246

\section{Performance evaluation of tuberose (Polianthes tuberosa L.) cultivars under Northern Telangana Zone}

\section{VIJAYA BHASKAR AND P. SURYANARAYANA REDDY ${ }^{1}$}

ABSTRACT : An experiment was conducted to assess the performance of four cultivars of tuberose to find out their suitability under the Northern Telangana Zone at Horticultural Research Station, Adilabad. Significant variation was observed among the cultivars for both vegetative and floral characters. Among the cultivars, 'Hyderabad Single' has recorded significantly highest plant height $(68.72 \mathrm{~cm})$ and number of leaves per plant (61.80). However, the number of days required for flowering was significantly highest (89.80) in 'Hyderabad Single' when compared with the 'Hyderabad Double' (76.60) which has recorded significantly lowest number of days. The number of florets per spike was significantly highest (35.80) with the cultivar 'Hyderabad Single'. Based on the vegetative and floral parameters the performance of 'Hyderabad Single' was found superior when compared with other cultivars under the Northern Telangana Zone conditions.

KEY WORDS : Tuberose, Plant height, Spike length, Number of florets per spike

HOW TO CITE THIS ARTICLE : Bhaskar, V. Vijaya and Reddy, P. Suryanarayana (2017). Performance evaluation of tuberose (Polianthes tuberosa L.) cultivars under Northern Telangana Zone . Asian J. Hort., 12(2) : 244-246, DOI : 10.15740/HAS/TAJH/12.2/244-246. 